\title{
Miranda
}

Revue pluridisciplinaire du monde anglophone /

Multidisciplinary peer-reviewed journal on the English-

speaking world

11 | 2015

Expressions of Environment in Euroamerican Culture /

Antique Bodies in Nineteenth Century British

Literature and Culture

\section{Roger Robinson, The Butterfly Hotel}

\section{Eric Doumerc}

\section{(2) OpenEdition}

1 Journals

Electronic version

URL: https://journals.openedition.org/miranda/7162

DOI: $10.4000 /$ miranda.7162

ISSN: 2108-6559

Publisher

Université Toulouse - Jean Jaurès

Electronic reference

Eric Doumerc, "Roger Robinson, The Butterfly Hotel", Miranda [Online], 11 | 2015, Online since 22 July 2015, connection on 08 September 2022. URL: http://journals.openedition.org/miranda/7162 ; DOI: https://doi.org/10.4000/miranda.7162

This text was automatically generated on 8 September 2022

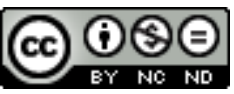

Creative Commons - Attribution-NonCommercial-NoDerivatives 4.0 International - CC BY-NC-ND 4.0 https://creativecommons.org/licenses/by-nc-nd/4.0/ 


\title{
Roger Robinson, The Butterfly Hotel
}

\author{
Eric Doumerc
}

\section{REFERENCES}

Roger Robinson, The Butterfly Hotel (Leeds: Peepal Tree Press, 2013), 70 p, ISBN 9781845232191

1 Roger Robinson is a Trinidadian poet and performer who has been based in London for a number of years now. He has had poems published in important anthologies like The Fire People (Edinburgh: Payback Press, 1998), edited by Lemm Sissay, IC3: The Penguin Book of New Black Writing in Britain, edited by Courttia Newland and Kadija Sesay (London: Penguin, 2000), and more recently Out of Bounds - British Black and Asian Poets, edited by Jackie Kay, James Procter and Gemma Robinson (Newcastle upon Tyne: Bloodaxe Books, 2012). He has also published a collection of short stories (Adventures in 3 D 2001) and two poetry collections, Suitcase (2004) and Suckle (2009). He was once a member of the Urban Poets Society and worked for a while as the programmer for Apples and Snakes performance poetry agency. He is well-known as a performer of his verse.

2 The Butterfly Hotel (Leeds: Peepal Tree, 2013) is Roger Robinson's latest poetry collection and can be seen as an extended meditation on the themes of exile, belonging and home. The collection is neatly divided into three sections, with each section dealing with a particular aspect of the poet's life. The first section is a series of vignettes about Brixton, the poet's home for a number of years now. The second section focuses on the themes of travelling and being an exile. The third part is concerned with Trinidad and the poet's relationship with his home island. The three sections are held together by the figure of the monarch butterfly, whose migration from one hemisphere to another mirrors the poet's own journey.

3 The first section of the collection is in fact a series of vignettes about Brixton street life and is slightly reminiscent of Linton Kwesi Johnson's Brixton poems in Dread Beat an' Blood (London: Bogle L'Ouverture, 1975). Like Johnson, Robinson is a keen social 
observer and his short pieces are glimpses into the street life of Brixton. The poem entitled "Brixton" is a rap-like descriptive piece roping in anything from the "guys at Twin Barbers" who "talk about Scarface like it was a documentary" to "the dancehall queens ... licking fried chicken grease/from their long neon-green fingernails at KFC" (The Butterfly Hotel, 15). As can be seen from these lines, there is a pictorial quality to Robinson's writing and he certainly has a painter's eye for detail. In "Brixton Summer", we learn that the "Jamaican girls of Brixton" are "Rubenesque and ripe" and that they have "shiny, bulging Buddha bellies". But Robinson is equally alert to Brixton's darker side and the opening poem of the collection is a tribute to the "angry young men" of Brixton:

Prayers for the boys on bmx's swarming the street with swithblade

stingers,

prayers for the long drips of lifeblood that spray the street like graffiti, prayers for the stench of curling weed smoke burning away the guilt, prayers for the young men caught on the wrong road in the wrong post code (The Butterfly Hotel, 13)

4 The second section is concerned with the theme of travelling and several poems look back on what must have been a painful experience for the poet, that is his coming to Britain and his new life as an "immigrant". Poems like "Month One" and "The Immigrant's Lament" chart the trauma of finding oneself in an alien environment that one does not understand. The poem entitled "Second-Hand Black Tweed Jacket" uses a charity shop garment as the metaphor for the process of adaptation and the common experience of immigration: wearing someone else's jacket is a bit like stepping into their shoes.

5 The figure of the butterfly constantly recurs throughout the collection and holds it together, with its association with the themes of migration, adaptation and transformation. For instance, the poem entitled "Blue Morpho Butterfly" is a tribute to the first Caribbean immigrants who came to Britain in 1948 on the SS Empire Windrush. The poems starts with an evocation of the well-known $\mathrm{BBC}$ footage showing the migrants walking down the walkway in their immaculate white suits and Panama hats:

Beneath his Panama hat, his mind held a Blue Morpho, its aqua wings moving in slow motion in one spot.

He saw the grey buildings and as they put the walkway out, the butterfly began to fly round the bowl of his skull. (The Butterfly Hotel, 34)

6 As the poems progresses, the butterfly becomes a symbol of the migrants' adaptation to Britain ("the butterfly's colour faded to clear sky") but also of their nostalgic yearning for their island homes.

7 In the third section of this collection, Roger Robinson literally and metaphorically revisits his home island, Trinidad, and this section is dominated by juxtapositions of his childhood memories with present-day Trinidad. The evocation of the poet's childhood and life as a young man in Trinidad can be nostalgic, as in "Where I'm From" with its reference to typically West Indian elements ("hops bread", "rock cake" and "Limacol" come to mind), but can also take in street characters like the break-dancer in "Mazda Man", or the juvenile delinquent in "Killah". The dark side of Trinidad is counterbalanced by a humorous look at things in "Sisyphus Liming in St James", "As All Boys Did", or "Kid/nap", about the carefree days of childhood. There is in this section a 
creative tension between the dark pieces about the colonial legacy ("Texaco Oil Storage Tanks") or present-day violence and insecurity ("In the Killing Season"), and the lighter poems like "The Church by the Hotel".

8 Some poems take the form of poetic prose, like "In the Killing Season", which is a graphic account of the mindless violence in present-day Trinidad:

On every drug corner, boys with twisted caps practice pulling their guns, training for death; every millisecond shaved could save a life of hurt. (The Butterfly Hotel, 62)

9 In "Kid/nap", the poet reminisces about his childhood and his uncle Clyde's wild days as a party-crasher. In this piece, one is reminded about certain eccentric characters in V.S. Naipaul's Miguel Street (London: André Deutsch, 1959) which are fondly remembered by the narrator:

At the wedding I wasn't sure that Uncle Clyde even knew the bride or groom, but as the music played he danced like he was the bride's proud father, making up new dances on the spot, in his creased clothes and uncombed hair (The Butterfly Hotel, 56)

whole, this collection strikes the right balance between nostalgic pieces about the vanished world of childhood, musings on the poet's own status as an exile caught between two cultures, and poems about life in multicultural London. Roger Robinson's elegant, subtle and terse pieces in The Butterfly Hotel confirm his status as one of the important voices in contemporary Black British and Caribbean poetry.

INDEX

Keywords: Black Britsh, Caribbean, Exile, Immigration, Linton Kwesi Johnson, V.S.Naipaul, Travelling, Trinidad, Windrush

Mots-clés: Anglo-antillais, Caraïbe, Exil, Immigration, Linton Kwesi Johnson, V.S.Naipaul, Trinidad, Voyage, Windrush

\section{AUTHORS}

\section{ERIC DOUMERC}

Maître de Conférences

Université de Toulouse Jean Jaurès

doumerceric@neuf.fr 